\title{
Separation of cellulose from industrial paper mill wastewater dried sludge using a commercial and cheap ionic liquid
}

\author{
Katarzyna Glińska, Mohammed Aqlan, Jaume Giralt, Esther Torrens, \\ Agusti Fortuny, Daniel Montané, Frank Stüber, Azael Fabregat, \\ Josep Font, Magdalena Olkiewicz and Christophe Bengoa
}

\begin{abstract}
Industrial wastewaters and their treatment are now placed at the heart of the environmental concerns that industries face. Some research work has been carried out in order to limit the impact of these wastes on the environment as well as their costs. In this study, wastewater dehydrated sludge (55\% wt. water content) from the paper industry was used to recover cellulose by using tetrakis(hydroxymethyl)phosphonium chloride, $\left[\mathrm{P}\left(\mathrm{CH}_{2} \mathrm{OH}\right)_{4}\right] \mathrm{Cl}$, ionic liquid as a solvent. The ionic liquid has shown remarkable results in terms of cellulose extraction in addition to its non-volatility and lower toxicity compared to organic volatile solvents. All cellulose, based on dry sludge, was recovered from the industrial dehydrated sludge with better operation conditions. The influence of temperature and the quantity of ionic liquid was preliminary studied in order to optimise the extraction conditions.
\end{abstract}

Key words | cellulose, industrial paper mill wastewater, ionic liquid, separation, sludge valorisation

\author{
Katarzyna Glińska \\ Mohammed Aqlan \\ Jaume Giralt \\ Esther Torrens \\ Daniel Montané \\ Frank Stüber \\ Azael Fabregat \\ Josep Font \\ Magdalena Olkiewicz \\ Christophe Bengoa (corresponding author) \\ Chemical Engineering Department, \\ Universitat Rovira i Virgili, \\ Avinguda dels Països Catalans 26, 43007 \\ Tarragona, \\ Spain \\ E-mail: christophe.bengoa@urv.cat \\ Agusti Fortuny \\ Chemical Engineering Department, \\ Universitat Politècnica de Catalunya, \\ Avinguda Víctor Balaguer, s/n, 08800 Vilanova I la \\ Geltrú, \\ Spain
}

\section{INTRODUCTION}

The global production of paper was 400 million tons in 2015 . Production is expected to increase to attain a world production of 550 million tons in 2050 (Faubert et al. 20I6). The pulp and paper industry is a regular and intensive consumer of water. It is considered as the third water user for its processes, behind the metallurgical and chemical industries (Buruberri et al. 20I5). Because of all this, the paper industry generates large amounts of wastewater in its processes, between 1.5 and $60.0 \mathrm{~m}^{3}$ per day and ton of paper produced. The treatment of this wastewater also generates between 40 and $50 \mathrm{~kg}$ of dried sludge per ton of paper produced (Adhikari \& Bhattacharyya 2015). Of this amount, 70\% comes from primary sludge and 30\% from biological sludge (Jaria et al. 2017). The management of waste sludge is a serious problem for the paper industry and the solution adopted is usually the incineration of it, often with a high economic cost and the consequent emissions of greenhouse gases (Faubert et al. 20r6). Other alternative possibilities widely used are application in agriculture as fertiliser, in building materials or for production of bioethanol (Farghaly et al. 2017).

However, the European paper industries, in association with the Confederation of European Paper Industries (CEPI), fully support the European framework directive on waste (2008/98/EC; EC 2008) which establishes a series of recommendations for proper waste management. Among them are the prioritisation of recycling over the incineration or deposition in agricultural fields and, finally, over the production of energy. Moreover, the European Commission Roadmap to Resource Efficient Europe (COM (2011) 571) (EC 20II) foresees the sustainability of Europe's economy by 2050, where waste is managed as a resource and energy recovery can only be used with nonrecyclable materials. This last milestone needs to be achieved in 2020 (Molina-Sánchez et al. 20I8).

The application of these directives has led to the production of new materials with the sludge produced during 
the wastewater treatment of the paper industry. Some examples are the production of pesticides and fertilisers or thermal insulation materials (Jaria et al. 20I7). Another possibility to enhance the residual sludge is to extract the cellulose, which can then be reused or converted into other materials with higher added value.

There are some conventional processes to recover the cellulose in the pulp and paper industries: kraft process (Reeve 2002); organosolv process (Chundawat et al. 20Io); viscose process (Zhang et al. 20I8); and lyocell (NMMO: $N$-methylmorpholine- $N$-oxide) process (Zhang et al. 2018). All the processes work well but they have some inconveniences: they are harmful to health owing the toxicity of the solvents, have a nauseating smell and are polluting. In addition, products or by-products cannot be easily used and valorised, or some of the organic solvents are difficult to recover and reuse. For this reason, it is necessary to find alternatives or new friendlier processes.

Moreover, it is widely known that ionic liquids have great ability to dissolve cellulose and other lignocellulosic biopolymers (Wang et al. 20I2). Ionic liquids were successfully used to precipitate cellulose from municipal sewage sludge (Olkiewicz et al. 20I5a). Thus, the technical feasibility of using ionic liquids to recover cellulose from an industrial sludge was investigated in the present study.

\section{METHODS}

\section{Materials}

The dehydrated sludge (55\% wt. water content) was provided by the international paper company GomàCamps, S.A., La Riba, Tarragona, Spain. The company, founded 250 years ago, has two paper fibre production lines, the first one with virgin cellulose pulp and the second with recycled paper. The sludge is a mixture of primary sludge coming from the physico-chemical treatment used to clean the recovered cellulose and the secondary sludge from a membrane biological reactor. Sludge is dried with air, stocked and is used to produce energy.

After reception, the dried sludge was stored at $4{ }^{\circ} \mathrm{C}$ in a fridge prior to use. Sludge was used as received. To realise the precipitation of cellulose, the sludge was suspended with deionised water until a final concentration of $5 \mathrm{~g}_{\text {dried sludge }} / \mathrm{L}$.

The ionic liquid used to recover cellulose from industrial dried sludge was tetrakis(hydroxymethyl)phosphonium chloride $\left(\left[\mathrm{P}\left(\mathrm{CH}_{2} \mathrm{OH}\right)_{4}\right] \mathrm{Cl}\right.$, hydrated ionic liquid, $80 \%$ in water, density $1.34 \mathrm{~g} / \mathrm{cm}^{3}$ ). It was supplied by Sigma-Aldrich.
Methanol, highest purity sulfuric acid, sodium bicarbonate, n-hexane, hydrochloric acid and magnesium sulfate monohydrate were provided by Sigma-Aldrich. Sodium tartrate, sodium chloride and diluted Folin reagent used for the sludge analyses were also provided by Sigma-Aldrich. The $80 \%$ phenol dissolution was prepared fresh. Deionised water was used in all laboratory procedures.

\section{Experimental procedure}

The process of the separation of cellulose from rehydrated dried sludge is summarised in Figure 1. The process was carried out using a similar method conducted for the extraction of lipids from primary sewage sludge (Olkiewicz et al. 20I5a). The method is as follows: the necessary volume of rehydrated sludge to have $1 \mathrm{~g}$ of total solids was placed in a round-bottomed flask. Then, to it was added a certain amount of ionic liquid, 2, 5 or $10 \mathrm{~mL}$, depending on the ratio of sludge to ionic liquid (sludge:IL) investigated. The flask containing the reagents, wastewater and ionic liquid, was heated at a determined temperature in an oil bath $\left(80^{\circ} \mathrm{C}\right.$ or $\left.100^{\circ} \mathrm{C}\right)$ for a fixed duration of time $(24 \mathrm{~h})$. The solution was mixed by a magnetic stirrer at $500 \mathrm{rpm}$. The flask was connected to a condenser on the top to condensate the liquid in the process. A blank experiment was conducted to see the effect of the ionic liquid on the recovery of carbohydrates. The conditions were: $24 \mathrm{~h}$ of time, $80^{\circ} \mathrm{C}$ of temperature and 1:10 ratio between sludge and water instead of ionic liquid. The rest of the procedures were the same.

During the reaction, the sludge was dissolved by the ionic liquid. This dissolution caused the formation of a gel because of the higher viscosity of the solution. When the reaction was over, the mixture was cooled to room temperature. Then, $5 \mathrm{~mL}$ of methanol was added to provoke the separation of phases and the precipitation of the cellulose. At that point, $10 \mathrm{~mL}$ of hexane was added to the mixture to easily separate the lipids from the rest of phases. The mixture was stirred and placed in a laboratory centrifuge at 3,500 rpm for 10 minutes. Two liquid phases were obtained. The yellow organic upper phase contained lipids and hexane. The aqueous liquid phase consisted of methanol, ionic liquid, and water. The precipitated phase containing cellulose was found in the bottom.

Firstly, lipids in hexane were separated using a pipette. Hexane was added again in order to complete lipid separation. The operation was repeated three or four times until the organic phase became clear after three or four additions of hexane, which meant that all the lipids had been extracted. 


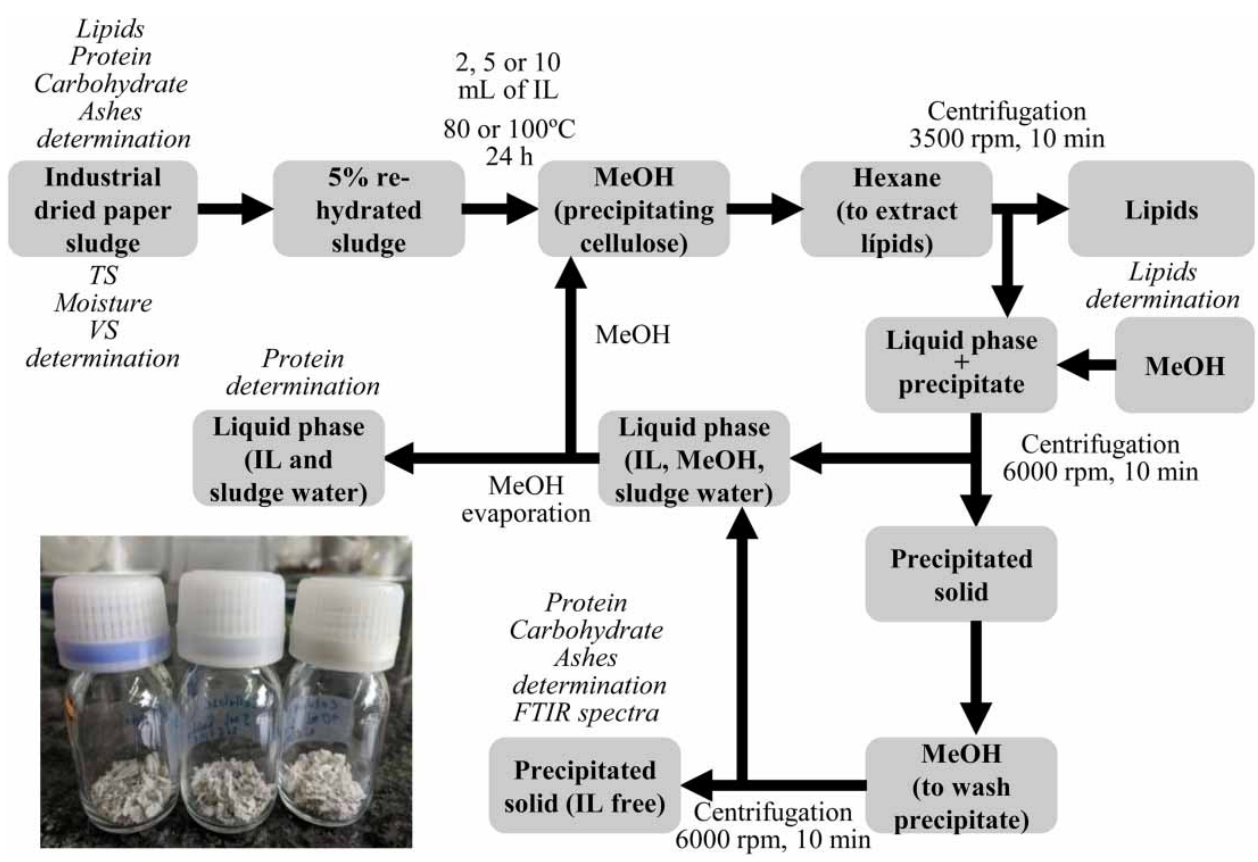

Figure 1 | Scheme of the experimental procedure of extraction of cellulose from industrial paper sludge with ionic liquid (MeOH, methanol).

Then, to recover the cellulose, the mixture of aqueous phase and precipitate was homogenised and placed in a laboratory centrifuge at $6,000 \mathrm{rpm}$ for 10 minutes. The aqueous phase was removed by a pipette. After this, methanol was added to the aqueous phase to eliminate the ionic liquid in the precipitated phase and centrifuged again. The process was repeated three or four times until the ionic liquid was totally eliminated in the aqueous phase, which was indicated by a white colour. The aqueous phase recovered from the extraction was also filtered to separate the traces of the precipitated phase. The precipitated solid obtained after filtration was put in an oven at $105^{\circ} \mathrm{C}$ for 24 hours in order to measure the total solid.

The final solid obtained after elimination of the aqueous and the organic phase contained traces of methanol. The methanol in the solid phase was evaporated in a rotary evaporator. The solid obtained was kept in a desiccator to avoid absorption of water. The solid phase or precipitate was then weighed.

To see the influence of the sequence on the operative protocol, another experiment was conducted, modifying the protocol of separation, centrifuging just after heating. The rest of the procedures were exactly the same, just adding methanol, then hexane, to both phases, solid phase and supernatant.

Total solids (TS), volatile solids and ash content were analysed to characterise the precipitate following the procedures described in the analytical characterisation. A sample of precipitated solid was then examined by Fourier transform infrared (FTIR) spectroscopy. The yield of precipitate was calculated based on $100 \mathrm{~g}$ total solid equivalent as:

precipitate yield $\%$

$=\frac{\text { precipitate obtained }[\mathrm{g}] \times \text { its fraction of } \text { dry weight }}{\text { wet sludge }[\mathrm{g}] \times \text { its fraction of dry weight }} \times 100$

\section{Analytical characterisation}

TS and volatile solids were both determined by the standard method 2540B (Rice et al. 2012). Ash content was also defined as described by the standard method 2540E (Rice et al. 2012).

The total carbohydrate composition was determined using phenol-sulfuric acid according to the Dubois method (Dubois et al. 1956); the absorbance was read at $480 \mathrm{~nm}$.

Protein composition was determined by the Lowry method (Lowry et al. 1951); the absorbance was read at $750 \mathrm{~nm}$.

Lipid composition from dried sludge was evaluated using a classical methodology with a Soxhlet apparatus and hexane as a solvent according to standard method 
5520E (Rice et al. 2012). Around $20 \mathrm{~mL}$ of wet sludge was first acidified to $\mathrm{pH}=2$, then $25 \mathrm{~g}$ of dry $\mathrm{MgSO}_{4} \cdot \mathrm{H}_{2} \mathrm{O}$ was added in order to eliminate the water and obtain a homogenous paste. The sludge was then left for 30 minutes. The solid obtained was crushed into fine powder. The powder was placed in a cellulose extraction thimble and covered with a glass wool. The extraction was then conducted using a Soxhlet and hexane solvent at 20 cycles/hour for 4 hours. Afterwards, the hexane was evaporated using a rotary evaporator. The lipids were stored in a desiccator to avoid water absorption and weighed on the next day. The lipid yield was expressed as gram of lipids per gram of dry sludge. The following equation shows how lipid yield was calculated:

lipid yield $\%=\frac{\text { fats and oils }[\mathrm{g}]}{\text { wet sludge }[\mathrm{g}] \times \text { fraction of dry solid }} \times 100$

The precipitated solid was analysed by FTIR spectroscopy to check the presence of carbohydrates. These samples, without any further preparation, were directly scanned using a Fourier Jasco FT/IR-600 Plus spectrometer with a diamond golden gate ATR (GS10542, Specac Ltd) reflectance cell.

\section{RESULTS AND DISCUSSION}

Table 1 presents the results obtained for the characterisation of the dried industrial sludge. As can be seen in the table, sludge was not totally dried as it contains $56 \%$ of water.

Table 1 | Characterisation of industrial paper wastewater dried sludge

\begin{tabular}{lll} 
& $\begin{array}{l}\text { Characterisation of dried } \\
\text { sludge }^{\mathbf{a}}(\%)\end{array}$ & $\begin{array}{l}\text { Mass of the fractions } \\
{\text { of dried sludge }(\mathbf{g})^{\mathbf{b}}}^{\mathbf{b}}\end{array}$ \\
\hline Moisture & $56.0^{\mathrm{c}}$ & 56.0 \\
Total solids & $44.0^{\mathrm{c}}$ & 44.0 \\
Ashes & $45.4 \pm 1.1^{\mathrm{d}}$ & 20.0 \\
Volatile solids & $54.6^{\mathrm{d}}$ & 24.0 \\
Carbohydrates & $54.8 \pm 3.0^{\mathrm{d}}$ & 24.1 \\
Protein & $2.6 \pm 0.2^{\mathrm{d}}$ & 1.1 \\
Lipids & $1.0 \pm 0.2^{\mathrm{d}}$ & 0.4 \\
Total & $103.8^{\mathrm{d}, \mathrm{e}}$ & $45.6^{\mathrm{e}}$
\end{tabular}

Values are mean, $\pm \mathrm{SD}, n=3$.

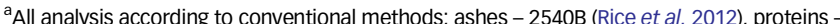
Lowry method, carbohydrates - Dubois method, lipids by extraction with Soxhlet apparatus ${ }^{\mathrm{b}} \mathrm{Calculated}$ on basis of $100 \mathrm{~g}$ of sludge as received.

${ }^{\mathrm{c}}\left(\%, \mathrm{w} / \mathrm{w}_{\text {sample }}\right)$.

${ }^{\mathrm{d}}\left(\%, \mathrm{w} / \mathrm{w}_{\mathrm{TS}}\right)$.

${ }^{\mathrm{e}} \mathrm{Sum}$ of ashes, carbohydrates, protein and lipids (corresponding to total solids).
Total solids represent $44 \%$ of the sludge. The composition of the total solids is $54.6 \%\left(\mathrm{w} / \mathrm{w}_{\mathrm{TS}}\right)$ volatile solids and $45.4 \%\left(\mathrm{w} / \mathrm{w}_{\mathrm{TS}}\right)$ ashes. There is a high value of ashes because the sludge contains inks and other metallic substances extracted during the washing of the recovered paper. The composition of volatile solids is essentially carbohydrates, $54.8 \%\left(\mathrm{w} / \mathrm{w}_{\mathrm{TS}}\right)$, basically cellulose; proteins, $2.6 \%$ $\left(\mathrm{w} / \mathrm{w}_{\mathrm{TS}}\right)$; and lipids, $1.0 \%\left(\mathrm{w} / \mathrm{w}_{\mathrm{TS}}\right)$. The values of proteins and lipids are essentially due to the presence of microorganisms from the secondary membrane bioreactor used to treat wastewater. This composition is totally different from the composition of primary sludge (Olkiewicz et al. 20I5a) where lipids accounted for $27.2 \%$ ( $\mathrm{w} / \mathrm{w}_{\mathrm{TS}}$ ), proteins for $24.2 \%\left(\mathrm{w} / \mathrm{w}_{\mathrm{TS}}\right)$ and carbohydrates for $26.2 \%\left(\mathrm{w} / \mathrm{w}_{\mathrm{TS}}\right)$. As expected, the composition of carbohydrates (cellulose) is higher in the industrial sludge but the high presence of ashes implies a better cleaning of the precipitate to allow the possibility to reuse cellulose.

In Table 2, the yields of cellulose and ash in precipitated material obtained after extraction of raw primary sludge with the ionic liquid are presented. The values are expressed as a percentage based on dry paper sludge. The results are obtained after reaction with two different temperatures using the same amount of ionic liquid $(1: 10 \mathrm{~mL})$ and the same time of reaction $(24 \mathrm{~h})$. In the first case $\left(80^{\circ} \mathrm{C}\right)$ $52.6 \%\left(\mathrm{w} / \mathrm{w}_{\mathrm{TS}}\right)$ of cellulose and $10.6 \%\left(\mathrm{w} / \mathrm{w}_{\mathrm{TS}}\right)$ of ash were obtained, whereas at $100{ }^{\circ} \mathrm{C} 53 \% \quad\left(\mathrm{w} / \mathrm{w}_{\mathrm{TS}}\right)$ of cellulose and $11.1 \%\left(\mathrm{w} / \mathrm{w}_{\mathrm{TS}}\right)$ of ash were obtained. As can be seen in Table 2, there is no influence of temperature on the cellulose and ash yield in the precipitated material: in both cases similar results were obtained. However, lower temperature conditions may have some effect and will be studied in the future.

The results of the blank experiment to see the effect of the ionic liquid on the recovery of carbohydrates are also

\begin{tabular}{|c|c|c|c|c|}
\hline \multirow[b]{2}{*}{ Temperature $\left({ }^{\circ} \mathrm{C}\right)$} & \multirow[b]{2}{*}{ Time (h) } & \multirow[b]{2}{*}{ Ratio sludge:IL ( $\left(\mathrm{g}_{\mathrm{TS}}: \mathrm{mL}_{\mathrm{LL}}\right)$} & \multicolumn{2}{|c|}{$\begin{array}{l}\text { Precipitated } \\
\text { material } \\
\text { (\%, dried sludge) }\end{array}$} \\
\hline & & & Cellulose & Ashes \\
\hline $80 \mathrm{BE}$ & 24 & 1:10 (water) & 48.8 & 37.0 \\
\hline 80 & 24 & $1: 10$ & 52.6 & 10.6 \\
\hline $80 \mathrm{PM}$ & 24 & $1: 10$ & 44.3 & 7.2 \\
\hline 100 & 24 & $1: 10$ & 53.0 & 11.1 \\
\hline
\end{tabular}

BE: blank experiment; PM: protocol modified by centrifugation just after $24 \mathrm{~h}$ heating. 
presented in Table 2. The unique difference was the use of water instead of ionic liquid in the 1:10 ratio experiment. As can be seen in the table, the recovery of carbohydrates is slightly lower but the quantity of ashes is more or less quadrupled. This demonstrates that the effect of ionic liquid is especially important for the separation of ashes from carbohydrates. The design of new ionic liquids must increase this separation until there is no presence of ashes in the carbohydrates.

The results of the experiment with a modified protocol are also presented in Table 2. The unique modification was to centrifuge the mixture just after heating. After centrifugation, methanol was added to both the solid and liquid phases. In the liquid phase containing the ionic liquid nothing occurred. No additional solid precipitated, thus signifying that all carbohydrates were in the solid phase. The ashes in this liquid phase, calculated by difference, were $38.4 \%$ dried sludge basis. This value is similar to the classical protocol. The addition of methanol in the solid phase, and after mixing, did not allow the separation of carbohydrates from the rest of the ashes. The content of ashes in the solid phase was 7.2\% dried sludge basis, a little less than obtained in the other experiments with the classical protocol. Moreover, the addition of hexane to liquid and solid phases to recover lipids showed that all lipids were in the solid phase. The lipids where recovered as in the classical protocol; the obtained value was similar, $0.8 \%$ dried sludge basis. This demonstrates that the sequence of operation does not have a great influence on the results of the separation. Prior centrifugation does not really improve the complete separation of compounds. Again, right design of ionic liquid will be required for a total separation.

In Table 3 we see the results obtained after reaction with three different ratios of sludge:IL $(2,5$ and $10 \mathrm{~mL})$ using the same temperature $\left(100^{\circ} \mathrm{C}\right)$ and the same time of reaction $(24 \mathrm{~h})$. As is shown in Table 3 , the cellulose and ash

Table 3 | influence of sludge:IL ratio on the yield of cellulose from industrial paper sludge using $\left[\mathrm{P}\left(\mathrm{CH}_{2} \mathrm{OH}\right)_{4}\right] \mathrm{Cl}$ ionic liquid $\left(100^{\circ} \mathrm{C}, 24 \mathrm{~h}\right)$

\begin{tabular}{lllll} 
& & & & \multicolumn{2}{l}{$\begin{array}{l}\text { Precipitated } \\
\text { material } \\
\text { (\%, dried sludge) }\end{array}$} \\
\cline { 4 - 5 } Temperature $\left({ }^{\circ} \mathbf{C}\right)$ & Time $(\mathbf{h})$ & Ratio sludge:IL $\left(\mathbf{g}_{\text {Ts }}: \mathbf{m L}_{\mathbf{L}}\right)$ & Cellulose & Ashes \\
\hline 100 & 24 & $1: 2$ & 56.9 & 18.3 \\
100 & 24 & $1: 5$ & 56.1 & 9.0 \\
100 & 24 & $1: 10$ & 53.0 & 11.1 \\
\hline
\end{tabular}

content depends on the amount of ionic liquid used. The less volume of ionic liquid was used, the more cellulosic material was obtained. With $2 \mathrm{~mL}$ of ionic liquid, $56.9 \%$ $\left(\mathrm{w} / \mathrm{w}_{\mathrm{TS}}\right)$ of cellulose was obtained, and with $10 \mathrm{~mL}, 53.0 \%$ $\left(\mathrm{w} / \mathrm{w}_{\mathrm{TS}}\right)$ of cellulose. However, lower amount of ionic liquid (1:2 sludge:IL ratio) gave higher amount of ashes, $18.3 \%\left(\mathrm{w} / \mathrm{w}_{\mathrm{TS}}\right)$, in the precipitated material, resulting in a cellulose material more contaminated with ashes. According to the results, the optimum ratio of sludge to ionic liquid is 1:5 ( $\left.\mathrm{g}_{\mathrm{TS}}: \mathrm{mL}_{\mathrm{IL}}\right)$ giving high amount of cellulose and low amount of ashes.

Table 4 shows the full characterisation of the entire process of recovery of cellulose by the ionic liquid. The experimental conditions were: $100{ }^{\circ} \mathrm{C}, 24$ hours of reaction and $1 \mathrm{~g}_{\mathrm{TS}}: 5 \mathrm{~mL}_{\mathrm{IL}}$ sludge:IL ratio. The first phase to be quantified was the lipids. After separation of the organic upper phase, hexane was evaporated and lipids were weighed. The obtained value, $1.1 \% \mathrm{w} / \mathrm{w}_{\mathrm{TS}}$, is almost identical to the value of lipids obtained by Soxhlet extraction and presented in Table $1,1.0 \% \mathrm{w} / \mathrm{w}_{\mathrm{TS}}$. The separation of lipids obtained with ionic liquid was complete, signifying that ionic lipids are more or less able to separate all fractions from the sludge in a single operation.

The determination of protein in the liquid aqueous phase by Lowry method (Lowry et al. I95I) provided a value of $1.4 \% \mathrm{w} / \mathrm{w}_{\mathrm{TS}}$. This value is more than $50 \%$ of the protein initially contained in the sludge, proving that the ionic liquid used for the recovery of cellulose is not totally selective for the separation of cellulose. The content of protein in the solid phase was determined by mass balance.

As can be seen in the table, the ionic liquid was also unable to eliminate all ashes in the precipitate. The amount of ashes found in the precipitate, $9.0 \% \mathrm{w} / \mathrm{w}_{\mathrm{TS}}$, is more or less $20 \%$ of the total ashes contained in the

Table 4 Characterisation of the fractions after their separation by ionic liquids (100 ${ }^{\circ} \mathrm{C}, 24 \mathrm{~h}, 1: 5$ sludge:IL ratio)

\begin{tabular}{llll} 
& $\begin{array}{l}\text { Organic } \\
\text { phase }\end{array}$ & $\begin{array}{l}\text { Liquid aqueous } \\
\text { phase containing } \\
\text { the ionic liquid }\end{array}$ & $\begin{array}{l}\text { solid phase: } \\
\text { precipitate }\end{array}$ \\
\hline Ashes $\left(\%, \mathrm{w} / \mathrm{w}_{\mathrm{TS}}\right)$ & - & 36.4 & 9.0 \\
Carbohydrates $\left(\%, \mathrm{w} / \mathrm{w}_{\mathrm{TS}}\right)$ & - & - & $56.1^{\mathrm{a}}$ \\
Proteins $\left(\%, \mathrm{w} / \mathrm{w}_{\mathrm{TS}}\right)$ & - & 1.4 & $1.2^{\mathrm{b}}$ \\
Lipids $\left(\%, \mathrm{w} / \mathrm{w}_{\mathrm{TS}}\right)$ & 1.1 & - & \\
Total $\left(\%, \mathrm{w} / \mathrm{w}_{\mathrm{TS}}\right)$ & 105.2 & & \\
\hline
\end{tabular}

${ }^{a}$ Calculated from the difference between the volatile solids in the precipitate and the proteins in the precipitate.

${ }^{\mathrm{b}}$ Calculated from the difference between the total proteins obtained from the dried sludge and the protein analysed in the liquid aqueous phase. 


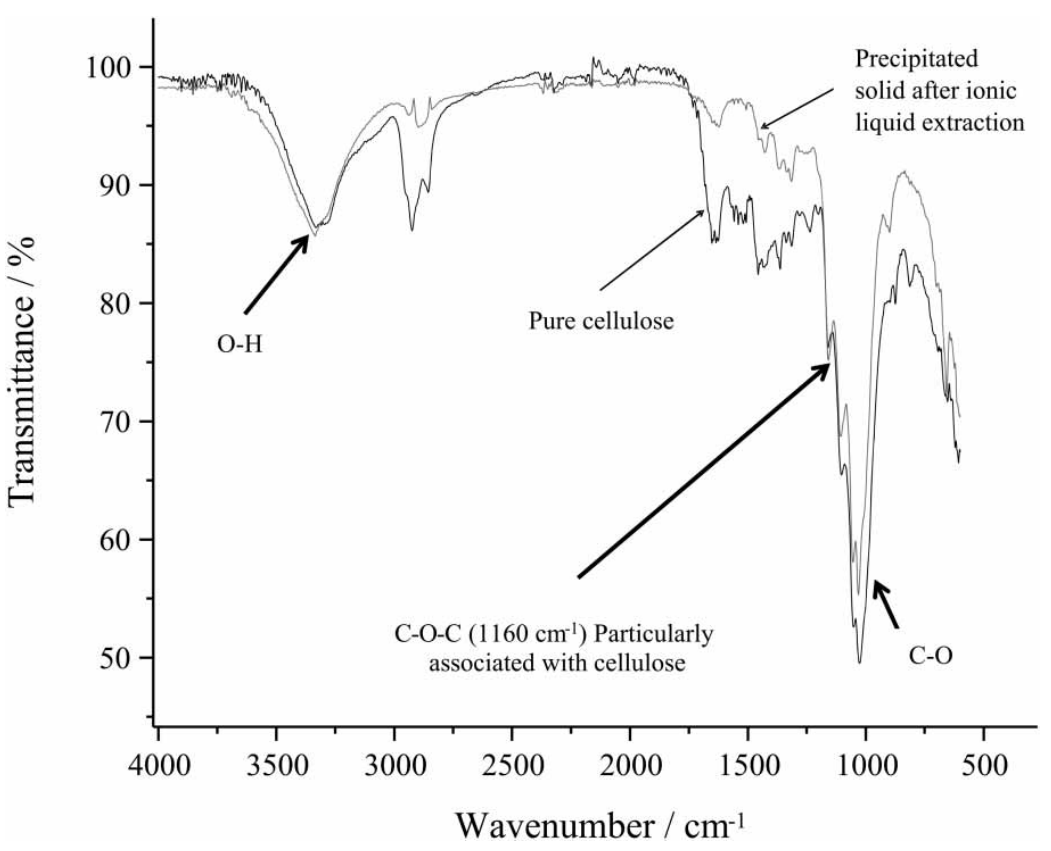

Figure 2 | FTIR analysis of precipitated solid after ionic liquid extraction and of pure cellulose.

sludge. The presence of these ashes is responsible for the final slightly dark colour of the precipitate.

The carbohydrates content in the precipitated solid after separation with ionic liquid was calculated from the difference between the value of volatile solids in the precipitate and the proteins in precipitate. The value of carbohydrates obtained by mass balance, $56.1 \% \mathrm{w} / \mathrm{w}_{\mathrm{TS}}$, is close to the initial carbohydrate content measured by Dubois method (Dubois et al. 1956) and presented in Table 1, 54.8\% w/ $\mathrm{w}_{\mathrm{TS}}$. Considering the accuracy of these results, it is possible to say that almost all the cellulose is in the precipitate. This is very important because a commercial ionic liquid is able to separate all the cellulose from a wastewater sludge. Specific design of new ionic liquids must be able to decrease the quantities of ashes and protein in the precipitate.

In order to confirm the structure of the obtained solid, the cellulose sample and precipitated solid were analysed by FTIR spectroscopy. Figure 2 presents the spectra of the precipitated solid after extraction of cellulose with ionic liquid. The broad peak around $1,035 \mathrm{~cm}^{-1}$ (assigned as the $\mathrm{C}-\mathrm{O}$ stretching vibration of carbohydrates) is presented in both samples. Also, a peak at $1,160 \mathrm{~cm}^{-1}$ in both spectra, which is assigned to C-O-C stretching vibration, is particularly associated with cellulose. Based on FTIR data it could be said that precipitated solid after ionic liquid extraction contains cellulose.

Additionally, the possibility of recoverability and reusability of the ionic liquid in a new cycle of purification is very important for the energetic and economic balance of the process. In the current work, recoverability and reusability of the ionic liquid were not checked as this study is a fast technical feasibility one. This was investigated in an older work using the same ionic liquid to extract lipids from microalgae (Olkiewicz et al. 20I5b). In this work, the stability of the ionic liquid was tested by ${ }^{1} \mathrm{H}$ NMR (proton nuclear magnetic resonance) spectroscopy, comparing fresh and used ionic liquid. The same peaks were found, signifying a high steadiness of the ionic liquid. No supplementary peaks appeared for the reused ionic liquid, suggesting its stability and allowing reusability. The recycling and reuse of the recovered ionic liquid were examined by carrying out four runs. All tests showed similar high performances of the recovered ionic liquid to that of the fresh ionic liquid, allowing its suitability in repeated processes.

Concerning the feasibility and economy of the process, the cost of ionic liquid, temperature and time of reaction of process are parameters that make the practical application of the process questionable when compared to currently applied processes. It is true that the cost of the ionic liquid is not cheap. But this work is a proof of concept. It is a first evaluation of the possibility to recover cellulose from industrial paper wastewater or sludge. The process is not yet optimised and needs a lot of extra work. For example, more selective and green ionic liquids should be optimised and designed, temperature should be 
decreased, time of reaction should be shortened, and sludge: IL ratios should be improved. Furthermore, this work was performed with dried sludge. As it demonstrated with municipal primary sludge in previous works, it is possible to work directly with wet sludge, avoiding high costs of drying operation (Olkiewicz et al. 2015a). The only thing that is currently questionable is the full recovery of ionic liquid. Separation and purification of ionic liquid after the recovery of the cellulose is a challenge. However, it has been demonstrated that ionic liquid can be reused as mentioned in the previous paragraph. Further studies with membrane separation processes might be able to recover the ionic liquid. Then, the problem of cost will also be solved. Finally, it is well known that the scale-up of the process to a semi-industrial continuous setup will improve the performances of the process. When all will be done, it will be then possible to compare the process with other currently applied processes.

\section{CONCLUSIONS}

The ionic liquid tetrakis(hydroxymethyl)phosphonium chloride has shown potential for the recovery of the cellulose from industrial paper sludge. The amount of carbohydrates measured by the conventional method in the paper sludge and the amount of cellulose recovered using ionic liquid method are comparable. The ionic liquid is able to dissolve ashes from paper sludge. The study shows a dependence between quantity of ionic liquid used for reaction and amount of cellulose recovered. The less ionic liquid used, the more cellulose obtained. It is necessary to study milder reaction conditions to optimise the process in order to reduce energy and therefore the cost of the process. It is necessary to study a purification process to further clean the cellulose.

\section{ACKNOWLEDGEMENTS}

The authors wish to acknowledge the company Gomà-Camps, S.A. for the kind collaboration during this project. Financial support for this research was provided by the Spanish Ministerio de Educación y Ciencia and the FEDER grant (CTM2015-67970). The authors are recognised by the Comissionat per a Universitats i Recerca del DIUE de la Generalitat de Catalunya (2014 SGR 1065) and supported by the Universitat Rovira i Virgili (2014PFR-URV-B2-35).

\section{REFERENCES}

Adhikari, G. \& Bhattacharyya, K. G. 2015 Impact of pulp and paper mill effluents and solid wastes on soil mineralogical and physicochemical properties. Environmental Monitoring and Assessment 187, 1-13.

Buruberri, L. H., Seabra, M. P. \& Labrincha, J. A. 2015 Preparation of clinker from paper pulp industry wastes. Journal of Hazardous Materials 286, 252-260.

Chundawat, S. P. S., Balan, V., Sousa, L. D. \& Dale, B. E. 2010 Thermochemical pretreatment of lignocellulosic biomass. In: Bioalcohol Production: Biochemical Conversion of Lignocellulosic Biomass (K. Waldron, ed.). Woodhead Publishing Series in Energy, 3, Woodhead Publishing, Cambridge, UK, pp. 24-72.

Dubois, M., Gilles, K. A., Hamillton, J. K., Rebers, P. A. \& Smith, F. 1956 Colorimetric method for determination of sugars and related substances. Analytical Chemistry 28, 350-356.

EC (European Commission) 2008 Directive 2008/98/EC of the European Parliament and of the Council of 19 November 2008 on waste and repealing certain directives. Official Journal of the European Union L 312, 22.11.2008, 3-29.

EC (European Commission) 20Ir Roadmap to a Resource Efficient Europe. Communication from the Commission to the European Parliament, the Council, the European Economic and Social Committee and the Committee of the Regions. COM(2011) 571 final. European Commission, Brussels, Belgium.

Farghaly, A., Elsamadony, M., Ookawara, S. \& Tawfik, A. 2017 Bioethanol production from paperboard mill sludge using acid-catalyzed bio-derived choline acetate ionic liquid pretreatment followed by fermentation process. Energy Conversion and Management 145, 255-264.

Faubert, P., Barnabé, S., Bouchard, S., Côté, R. \& Villeneuve, C. 2016 Pulp and paper mill sludge management practices: what are the challenges to assess the impacts on greenhouse gas emissions? Resources, Conservation and Recycling 108, 107-133.

Jaria, G., Silva, C. P., Ferreira, C. I. A., Otero, M. \& Calisto, V. 2017 Sludge from paper mill effluent treatment as raw material to produce carbon adsorbents: an alternative waste management strategy. Journal of Environmental Management 188, 203-211.

Lowry, O. H., Rosebrough, N. J., Farr, A. L. \& Randall, R. J. I95I Protein measurement with the Folin phenol reagent. Journal of Biological Chemistry 193, 265-275.

Molina-Sánchez, E., Leyva-Díaz, J. C, Cortés García, F. J. \& Molina-Moreno, V. 2018 Proposal of sustainability indicators for the waste management from the paper industry within the circular economy model. Water 10, 1014.

Olkiewicz, M., Plechkova, N. V., Fabregat, A., Stüber, F., Fortuny, A., Font, J. \& Bengoa, C. 2or5a Efficient extraction of lipids from primary sewage sludge using ionic liquids for biodiesel production. Separation and Purification Technology 153, $118-125$

Olkiewicz, M., Caporgno, M. P., Font, J., Legrand, J., Lepine, O., Plechkova, N. V., Pruvost, J., Seddon, K. R. \& Bengoa, C. 20I5b A novel recovery process for lipids from microalgae for 
biodiesel production using a hydrated phosphonium ionic liquid. Green Chemistry 17, 2813-2824.

Reeve, D. W. 2002 The Kraft Recovery Cycle. In: 2000 Kraft Recovery Short Course, Course Notes (E. Rosed, ed.). Tappi Press, Atlanta, GA, USA, pp. 1-16.

Rice, E. W., Baird, R. B., Eaton, A. D. \& Clesceri, L. S. 2012 Standard Methods for the Examination of Water and Wastewater, 22nd edn. American Public Health Association/
American Water Works Association/Water Environment Federation, Washington, DC, USA.

Wang, H., Gurau, G. \& Rogers, R. D. 2012 Ionic liquid processing of cellulose. Chemical Society Reviews 41, 1519-1537.

Zhang, S., Chen, C., Duan, C., Hu, H., Li, H., Li, J., Liu, Y., Ma, X., Stavik, J. \& Ni, Y. 2018 Regenerated cellulose by the lyocell process, a brief review of the process and properties. Bioresources 13, 4577-4592.

First received 12 November 2018; accepted in revised form 17 May 2019. Available online 3 June 2019 